\title{
«Нашого цвіту - по всьому Світу»: до виходу в світ Антології сатири і гумору української діаспори у двох книгах «Право на сміх» (за матеріалами часописів «Лис Микита», «Мітла», «Комар», «їжак»)
} Іван ДЗЮБА академік НАНУ (ㄱ Дзюба I., 2021

У видавництві «Либідь за сприяння Міжнародного фонду «Відродження» 2020 року вийшло у світ непересічне видання - антологія сатири і гумору української діаспори «Право на сміх». Основу щедро ілюстрованого двокнижжя великого формату в кольоровій оправі склали публікації рідкісних на сьогодні сатиричних журналів української діаспори.

До першої книги увійшли найцікавіші тексти, шаржі та карикатури з багатьох десятків чисел «Лиса Микити» - часопису, який українці видавали на чужині сорок років. Це неповторне явище в історії сатирико-гумористичної преси. Зі шпальт цьо20 часопису читач має можливість ознайомитися із талановитими письменниками, публіцистами, журналістами, митцями українського походження зі США, Канади, Німеччини, Польщі, які не втратили актуальності й донині.

До другої книги антології увійшли вибрані різножанрові сатиричні й гумористичні твори з календаря-альманаху «Мітла» (Аргентина) $і$ часописів «Комар», «Н̈нак» (Німеччина), які є немов уривками з літопису нелегкого, а все ж змістовного, активного життя українців, що їх доля закинула в чужі світи.

\section{1 Рецензія на книги:}

- Право на сміх. Антологія сатири і гумору української діаспори / упоряд., авт. передм. І. Дзюба. Київ: Либідь, 2020. Кн. 1: Часопис «Лис Микита». Сатира, гумор, карикатура. 1948-1985. 424 с.: іл.

- Право на сміх. Антологія сатири і гумору української діаспори / упоряд. І. Дзюба. Київ: Либідь, 2021. Кн. 2: Гумористика «Мітли» і «Комара/Їжака». 360 с.: іл. 


\title{
UKRAINIAN SEEDS MAKE A GOOD CROP ALL OVER THE WORLD: dedicated to the publication of the Anthology of Satire and Humor of the Ukrainian Diaspora in two books "The Right to Laughter" (based on the magazines "Lys Mykyta", "Mitla" ("La escoba"), "Komar", "Yizhak"
}

\author{
Ivan Dziuba \\ Academician of the National Academy of Sciences \\ of Ukraine
}

In 2020, the Lybid publishing house, with the assistance of the International Renaissance Foundation, published an outstanding publication - an anthology of satire and humor of the Ukrainian diaspora: "The Right to Laughter". The basis of the generously illustrated large-format two-volume book in the color frame was the publications of today's satirical magazines of the Ukrainian diaspora.

The first book includes the most interesting texts, cartoons, and caricatures from many dozens of "Lys Mykyta" issues. That is a magazine that Ukrainians published abroad for forty years. Also, it is a unique phenomenon in the history of the satirical and humorous press. From the pages of this magazine, the reader has the opportunity to get acquainted with talented writers, publicists, journalists, artists of Ukrainian origin from the USA, Canada, Germany, Poland, which have not lost relevance to this day.

The second book of the anthology includes selected satirical and humorous works of various genres from the calendar-almanac "Mitla"("La escoba") (Argentina) and magazines "Komar", "Yizhak" (Germany), which are like excerpts from the chronicle of difficult, but meaningful, active life of Ukrainians that have been thrown into other worlds by their destiny. 
Усім небайдужим добре відомо, українці - найдревніша, а отже, і найсміхотливіша нація в нашій Галактиці. Вони завзято й невтомно сміються ще з часів царя Гороха (коли Землі було трохи) і царя Панька (коли Земля була тонка). Сміються переважно із самих себе (голений зі стриженого, шолудивий із голомозого, бородатий із пелехатого, босий із узутого, дука 3 голоти, щирий із поміркованого, радикал із реаліста, москвофіл із русофоба, виборець із нардепа, слуги народу із самого народу, - і навпаки). А із входженням у світове життя й модернізацією горизонти сміху розширилися, і сам він зробився барвистішим і експансивнішим. Українське сміхацтво оформилося як сміхова культура, чи, інакше, як карнавальність, ще задовго до сакралізації М. Бахтіним цього веселого терміна.

Однією з особливих прикмет нескінченного українського сміху є те, що ми, українці, часто сміємося й за тих історичних катавасій, коли мали би плакати. Ну що ж, мовляв, так історично склалося...

А воно не раз складало-

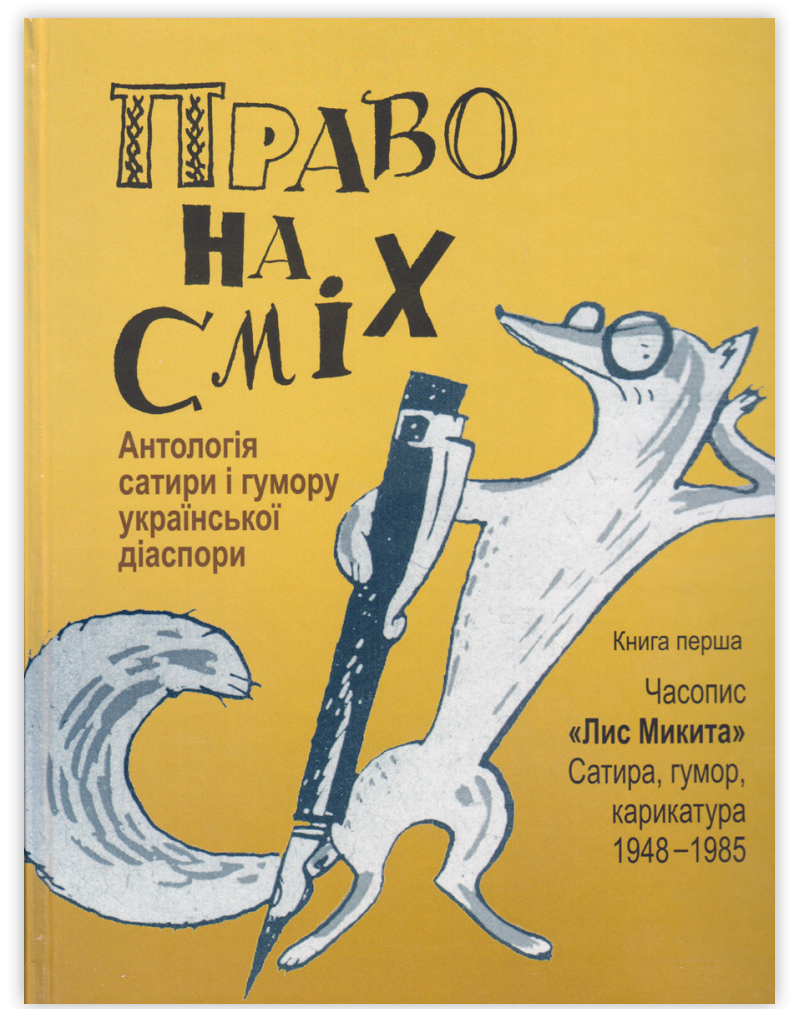
ся. От, для прикладу, промовистий історичний казус (чи не з перших!), котрий описав Іван Петрович Котляревський: коли греки «спалили Трою» $\mathrm{i}$ «зробили $з$ неї скирту гною», то наші троянці не задумалися над своєю планидою, а засміялися на щасливо вцілілі кутні, чим добре збадьорилися, і під проводом «парубка моторного», славного козака Енея, таким собі реготливим гуртом гультіпак-волелюбців подалися звеселяти понурий середземноморський цивілізаційний ареал - дорогою до провіщаного майбутнього Риму.

Так і почалося оте славнозвісне розсіювання нашого цвіту по всьому світу, або: «Де наше не пропадало», - яке триває й досі. Хоч і не так утішно, як колись. Бо Трою палили не раз і не тільки греки - дурне діло нехитре. Навіть уже й не саму Трою, а ії̈ Руїни розворушували. А на Олімпі не було вже тих, хто колись підігравав Енеєві. У Єв- 
ропі нас, кажуть, не ждали. Тож коли в пізнішу добу вигнанська доля спіткала зовсім інших історичних персонажів - величного гетьмана Мазепу, а з ним і молодого гетьмана, високоосвіченого, на відміну від самоука Енея, латиніста і європеїста Пилипа Орлика, то навряд чи їм було до сміху - не той історичний контекст.

Саме з Пилипа Орлика го-

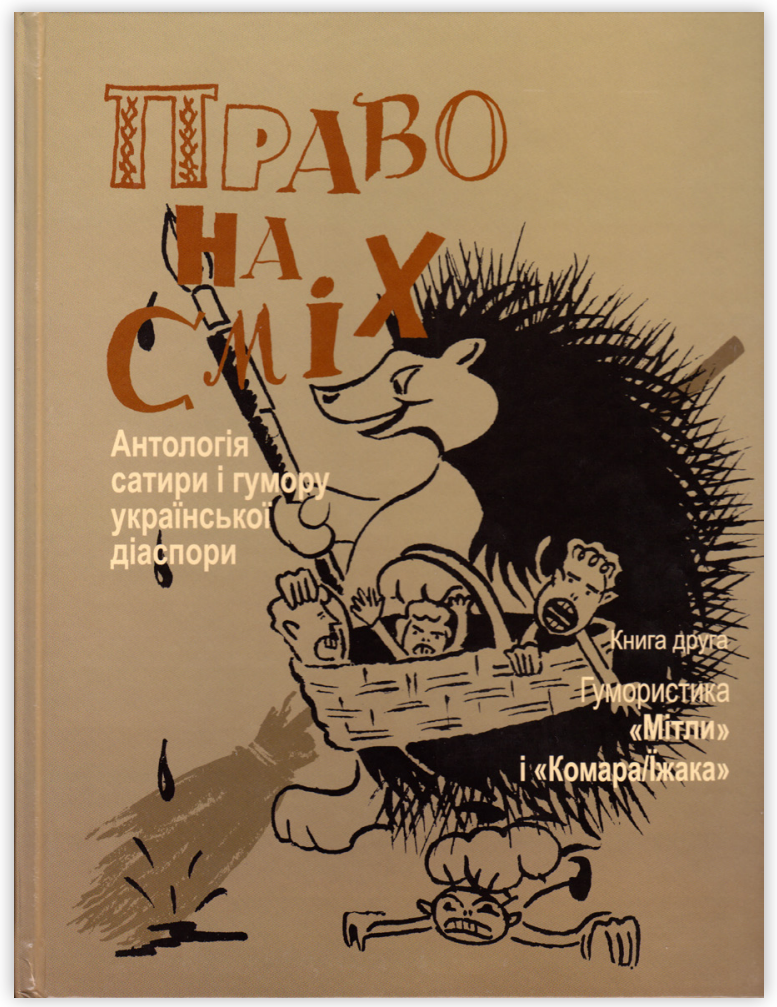
дилося б починати нашу Антологію, - бо ж був Пилип Орлик не лише гетьманом-вигнанцем, автором першої української конституції та численних маніфестів до козацтва й до традиційно глухуватих європейських достойників, а й літератором, поетом, можна сказати, публіцистом і полемістом - не без вигнанського сатиричного хисту.

Два наступні покоління українських троянців мали вже сучасний статус - політичні емігранти. Це, перше, ті, хто залишив Україну після поразки УНР. А потім ті, хто опинився в Європі під час та після Другої світової війни. Між цими двома хвилями еміграції чверть століття, але скільки спільного ідеологічна мотивація, масовість, і ворог-насильник той самий. Але є й суттєво відмінне. Після поразки УНР рідну землю змушені були залишити українські вояки, що деякий час ще продовжували боротьбу, та частина інтелігенції, що пов’язала свою долю з УНР.

Ця інтелігенція знайшла притулок у сусідніх з Україною державах - Чехословаччині, Польщі (до складу якої тоді входила частина українських земель), сподіваючись продовжувати політичну і культурну роботу. I таки продовжувала їі. Українська політична еміграція з Великої України, солідарно з українцями Західної України, створила в Празі й Варшаві свої громадські й наукові осередки, змогла розгорнути видавничу діяльність (говоримо тут саме про нову еміграцію, а не про відомі здобутки галицького суспільства).

Тепер зброєю нашої еміграції залишалося вільне слово. Воно супроводжувало й надихало її. А де вільне слово, там і вільний сміх - 
як форма самоконтролю і спосіб досягнення рівноваги. Проте сміх цей, сміх утікачів, був гіркий.

Славетний на Батьківщині лірик Олександр Олесь у вигнанні стає і скорботним сатириком, звинувачуючи своє покоління в бракові сил - у провинах не лише власних, а й тих, яким було чи не триста літ. Біль утрати Батьківщини обертається спазмами національної самокритики, у якій панують наші вічні, ще Мазепині мотиви: «Десять об’єднань і безліч роз'єднань. -/ Як не радіти дурним ворогам?». А ось іще промовисте:
Не вороги в боях нас розбивали, Палили збіжжя і хати.
Не вороги серця нам виривали, Не вороги вели нас на хрести.
Не вороги нас вигнали із краю, Щоб ми блукали по світах...
Не вороги... Самі ми зруйнували
В своїй пустелі інший храм.
Стократ самі ми відчиняли
Ворота нашим ворогам.

Це вірш 1921 року. І це вже перегук не так із Мазепою, як із Винниченком, який приблизно в той самий час, полемізуючи з обвинуваченнями на свою адресу й дещо спрощуючи, писав, що українську владу вигнали не більшовики, а українські селяни, яким вона не дала землі, через супротив поміщицтва і правих партій.

В Олеся, від природи «співця краси», цього соціального аспекту немає, у нього національна трагедія постає в ліричному чи морально-риторичному вимірі, а провина за поразку лягає на неспроможність українства як такого одностайно протистояти ворогам - отож і нарікання на внутрішні чвари та незгоди. Ці нарікання є і в Євгена Маланюка, але як частина політично наснаженіших і пристрасніших мотивів, близьких до патосу Дмитра Донцова. I вже молодше покоління цієї еміграції - Юрій Липа, Олена Теліга, Олег Ольжич (син Олександра Олеся) - ближчі до Маланюка, але йдуть далі за нього.

Юрій Липа у своїх працях запропонував нову геополітичну концепцію, що мала враховувати реальне становище України в Європі XX ст., Олег Ольжич у пристрасному засудженні вічних українських усобиць дав глибокий аналіз їхніх причин і наслідків.

Олена Теліга густими сатиричними барвами змалювала український (і вселюдський!) тип «партачів життя», які не здатні підпорядкувати себе великій справі, - й унаочнила зразок особистої жертовності в боротьбі за свободу свого народу. За трагічних історичних 
обставин, коли гітлерівські «визволителі» від більшовизму несли Україні свій терор, - вона, як і Олег Ольжич, показала можливість стояти проти обох ворогів - у підпільних націоналістичних структурах.

Із цього погляду цивільні втікачі від радянської влади (1943 р. та ін.) були в складнішій політично-психологічній ситуації. Адже ця величезна маса людей мовби відступала разом із німецькою армією перед наступом радянської. Радянська пропаганда називала їх колаборантами, які прагнуть уникнути відповідальності.

Західний обиватель схильний був прийняти таку версію, а уряди західних держав у ряді випадків погоджувалися на вимоги СРСР повертати біженців назад, що призводило до численних трагедій і жахливих самогубств приречених людей. Над цим не можна було не задуматися. Західну громадськість вразив памфлет Івана Багряного «Чому я не хочу повертатися до СССР» (1944), перекладений багатьма мовами. Наче пелена впала з очей тим, хто не знав про реалії життя й політичний терор у «Країні Рад».

Тут треба зауважити, що в потік біженців із радянської України вливається потужна хвиля втікачів із Галичини, із Західної України взагалі - вони лише кілька років побули «під совітами», але встигли відчути «принади визволення» $\mathrm{i}$, як могли, рятувалися. Лави української еміграції поповнилися новими силами європейськи освіченої і відповідно орієнтованої інтелігенції, діячів культури і мистецтва (а їх було чимало!), і це ще більше підвищило її інтелектуальний потенціал, що невдовзі дало про себе знати.

Тим часом на зміну ілюзіям західних політиків про наміри Сталіна приходить «холодна війна», і ставлення до біженців із СРСР у західних зонах окупації Німеччини та Австрії стає прихильнішим. Вони використовують свої можливості самоорганізації, при цьому, під впливом атмосфери західної політичної свободи, відбувається й певне розшарування за ідеологічними і культурними ознаками.

Дістає розвитку емігрантська преса, починають з'являтися гумористичні й сатиричні видання, що уяскравлюють інтелектуальну привабливість українського слова. Очевидного розквіту вони досягнуть тоді, коли емігранти хвиля за хвилею переселяться за океани у Північну й Південну Америку, Австралію. Скрізь вони покажуть неабияку здатність до адаптації, засвоєння нового житейського й політичного досвіду, з еміграції стануть діаспорою, тобто стабільною національною групою на чужині. А свої проблеми обговорюватимуть у вільній пресі, використовуючи і «право на сміх».

Сміючись, як завжди, і з самих себе, і з прикрощів життя, і зі своїх ворогів та недоброзичливців, близьких і далеких, і з негараздів світового устрою та курйозів людської моралі й мислення. Як це в них ви- 
ходило чи не виходило, - побачимо і з цієї Антології, що складається 3 двох книг.

3 її сторінок читач має можливість ознайомитися не лише 3 добірками з численних сатиричних журналів, що виходили українською мовою на різних континентах, але й з окремими книжками найпопулярніших у діаспорі гумористів і сатириків.

Варто сподіватися, що читач оцінить багатство їхніх мотивів і сюжетів, житейську спостережливість, виразність вислову. А ще - унікальну життєздатність нашої політичної еміграції-діаспори, яка навіть після втрати Батьківщини, за найтяжчої історичної катастрофи i, здавалося, світового тріумфу Зла не втратила віри в ідеали Свободи, що прийде на рідну землю, не розгубила віри у свій народ, який переживе найтяжчі часи, - зберігала те, що ми втрачали, і створювала нові мистецькі й інтелектуальні цінності - цілий пласт національної культури, який ми ще мало знаємо.

Досвід творців української діаспорної преси може бути повчальним для нас і сьогодні. Адже наша Троя завжди була й залишається тяжко загроженою. Тому мусимо розраховувати тільки на себе і свою тверезу самооцінку, бо часи не Енеєві, і на Олімпі прихильних до нас богів немає. 